\title{
Content Analysis of the Studies in Turkey on the Ability of Critical Thinking
}

\author{
Seyat Polat ${ }^{\mathrm{a}}$
}

Mevlana (Rumi) University

\begin{abstract}
Critical thinking, along with other skills, is included as a basic skill in the constructive education program that has been in use in Turkey since 2005. Therefore, a large increase has been observed in studies on critical thinking skills since 2005. In this frame, the present study was conducted in order to systematically examine research papers on critical thinking skills in terms of several variables published between the years 2005 and 2014 in national journals which are indexed by SSCI and the ULAKBIM social sciences database. In this context, a total of 93 articles from 29 different journals were analyzed using the NVivo 10, SPSS 18, and Microsoft Excel programs and performing content analysis which is widely used in qualitative studies. According to the findings, a large number of the studies were from 2011 and 2013, and they were carried out by female researchers on prospective teachers using quantitative methods and descriptive research design; they used scales as data collection tools. However, it was found that only one study was made at the primary school level and there have not been any researches performed in kindergartens, English or Math classes, or for improving a model.
\end{abstract}

Keywords: Critical thinking $\bullet$ Content analysis $\bullet$ Studies in Turkey $\bullet$ NVivo

a Correspondence

Seyat Polat, Department of Curriculum and Instruction, Faculty of Education, Mevlana (Rumi) University, Konya 42003 Turkey

Research areas: Critical thinking; Values education; Metacognitive strategies

Email: seyatpolatagmail.com 
Thinking is one of the concepts that has attracted the most interest since the beginning of man's existence. Therefore, it is very hard to identify the first studies on thinking. Aristotle, however, the great scientist from ancient Greek thought, said that thinking is composed of reason and logic is a tool which takes one to the truth. Descartes, one of the thinkers from the $17^{\text {th }}$ century, puts thinking on par with being suspicious. According to Ibni Haldun, thinking means searching for reasons in an event or situation (Hançerlioğlu, 2007). Dewey (1910) defines thinking, just as feeling the symptoms of rain, as recognizing what will happen in the future and taking steps accordingly. Mevlana indicates that thinking is a dream which humans relive in their mind, and he also defines this dream as a potential strength which takes humans to their goals. Mustafa Kemal Atatürk identifies the ability to think as a more powerful weapon than artillery or rifles (Kocahanoğlu, 2003; Nahifi \& Çelebioğlu, 2008). Because the history of thinking as a concept is based on the past and highly intensified, various skills were put forward on this concept; the importance of high-level thinking and conscious thinking especially began to emerge. One of the concepts which meets these requirements is the ability of critical thinking.

The first serious studies on critical thinking started in the 1960's. These studies are generally noted for evaluating written expression (Kazanc1, 1989). The ability of critical thinking was first presented by Perry in the 1960's and then it was modeled in the 1980's by Paul et al (Özden, 2000). Critical thinking was first defined in 1962 by Ennis. In the 1980's, Ennis and Beyer handled critical thinking differently. According to Ennis (1985), critical thinking is focused on deciding what to believe and what to do; it is reflective and mentally based. Additionally, critical thinking includes hypotheses, questions, and alternatives. Beyer (1987) defines critical thinking as requiring an analysis between connections together with assessment of the truth and certainty of knowledge.

In Turkey, studies on critical thinking were first done by Kazancı in 1989 and Cüceloğlu in 1995. Cüceloğlu defines critical thinking as the recognition of the process of self-thought by considering the thinking processes of others with the aim of understanding situations about one's environment by applying what one has taught one's self. Cüceloğlu also believes that it is an active and organized mental process. Kazancı defines critical thinking as the total process of skill, style, and information which is included in argumentation and assessment in regard to the validity and consistency of a problem's cultural, social, and scientific criteria. The first thesis study was a master's thesis titled "Enhancing the Critical Thinking of Preparatory University Students of English at the Intermediate Level" by Özçınar in 1996.

The studies mentioned above are important because they have pioneered other studies, every new study being started and shaped with the research from previous studies (Gülbahar \& Alper 2009). As a result, the studies in education aim to increase the quality of the educational system and its functionality (Göktaş et al., 2012). Karadağ (2009) has asserted that focusing on research related to education is highly important because of the examination of the quality of education, the availability of the achieved results, and the quality of these studies. Therefore, the analysis of studies done on a prominent subject would help researchers look at these subjects from a holistic perspective. For instance, Varışoğlu, Şahin, and Göktaş (2013) have evaluated articles published in journals indexed by SSCI and the ULAKBIM social sciences database to identify the tendencies in educational research in Turkey according to their quality and quantity. Additionally, Saban (2008) systematically analyzed studies which were written in Turkish on the theory of multiple intelligence. Göktaş et al. (2012) analyzed educational research published between 2005 and 2009 in Turkish journals which were indexed by SSCI and the ULAKBIM data base. They evaluated the tendencies of the studies in terms of their type, method, subject, data collection tools, and sample. Gülbahar and Alper (2009) made a content analysis of studies which were carried out in the instructional technologies field.

With the result of deep changes in the educational programs seen in Turkey since 2005, constructive educational programs have begun to be applied. Among various reforms brought by this educational program, basic skills have been given importance. There are various objectives and activities about critical thinking in this program. Therefore, many researches have been done to gain critical thinking skills since 2005 (Bayat, 2014; İskifoğlu, 2014; Yangin, 2014). Thus, comprehensive analysis is needed to see exactly how these studies have been handled and which aspects of critical thinking skills were not examined. It is thought that if studies on the same topic are organized under certain themes and critiqued in the same manner, it can contribute to the instruction of social sciences. Consequently, 
this research aims to systematically analyze in terms of certain variables the studies on critical thinking skills between the years 2005 and 2014 in national journals which have been indexed by SSCI and the ULAKBIM data base. This research is believed to make a significant theoretical contribution to the literature in that this is the first study done nationally which comprehensively analyzes the articles in national journals which are indexed by SSCI and the ULAKBIM data base. The studies on critical thinking in this research are analyzed according to research design, research method, data collection instrument, sample type, sample features, and number of participants. Along with this, the difference between experimental studies were determined in terms of their application process; number of participants both in experimental and control groups; the scores of pretest, post-test, retention, and attitude tests. In this respect, the current study is believed to contribute greatly to the literature because it puts forth how studies on critical thinking skills were carried out over a 9-year-period from 2005 to 2014.

\section{Method}

Qualitative research methods and techniques were used in this study. This study was conducted using the content analysis model, which is common in qualitative studies. According to Saban (2008), content analysis is the thematic analysis of impressed, visual, and other materials in terms of certain categories by reviewing them systematically. Glesne (2013) describes content analysis as thematic analysis. In these kinds of analyses, the researcher focuses on analytical techniques to look for themes and patterns in the data. Patton (2014) defines content analysis as any kind of qualitative data reduction and interpretation attempt in order to determine the basic differences and meanings by identifying voluminous qualitative materials.

\section{Extent of Research}

A total of 93 articles were analyzed in this research. The purposeful sampling method was used in the determination process of these studies. In purposeful sampling, the researcher uses their own judgment about which resources to choose and then takes the most suitable ones for research purposes into the sample (Balc1, 2011). In these studies, the purposeful sampling method was used because this study involves only research on critical thinking skills. Therefore, the studies analyzed in this research don't reflect the whole volume of literature on critical thinking skills. The following parameters were used in the selection process of the sample.

This study analyzed only the articles on critical thinking skills using .pdf or .doc file extensions and were indexed in the databases of ULAKBIM ( $n=$ $66)$ and SSCI $(n=27)$ in Turkey. Only the articles on critical thinking skills in Turkish and English which were written between the years 2005 and 2014 in Turkey were included in this research. This study doesn't involve any theses or reports about critical thinking written solely in Turkish. The reason for this is the excessive number of theses and reports as well as the limits of deep analysis and synthesis (Çalık \& Sözbilir, 2014).

\section{Data Collection}

16 questions were used in the analysis of 93 studies on critical thinking skills. Each of these questions was considered as a main theme for the content analysis guideline used in the study. Previous studies (Gülbahar \& Alper, 2009; Saban, 2009; Sözbilir \& Kutu, 2008; Varışoğlu et al., 2013) were taken into consideration while determining the questions and a form was developed. This form was presented to experts who use qualitative research methods in their studies. They consulted theses consisting of qualitative research methods and some necessary revisions were done in accordance with their comments. The final form consists of 16 sections. As a result, studies were analyzed according to:

(i) subject, (ii) year of publication, (iii) gender of the researcher, (iv) research design, (v) method, (vi) data collection instrument, (vii) sample type, (viii) sampling method, (ix) number of participants, $(x)$ which journal it was printed in, (xi) number of authors, (xii) class of study in which the experimental study was carried out, (xii) application time of the experimental study (weekly), (xiv) difference between the scores of experimental and control group's pretest, posttest, retention, and attitude scores, $(x v)$ education level of the students participating in experimental studies, and ( $x v i)$ frequency of words.

\section{Validity and Reliability}

Studies regarding the validity and reliability of this research were done in accordance with the recommendations of Miles and Huberman (1994) and Merriam (2013) as follows: (i) To 
increase the internal validity of this research, expert opinions were sought about the questions in the content analysis guideline along with the subject and methodology of the research. (ii) To ensure the internal validity of the study, analysis was performed within the framework of data collection and data analysis until it reached a point of certainty, and adequate time was spent for this work. (iii) To improve the exterior reliability of the research, the research process and what was done during this process were explained in a detailed manner. In this respect, the research model, data collection process, and analysis and interpretation of data were defined richly and densely. (iv) Nvivo 10 reports were examined by a researcher who is an expert in qualitative research in order to ensure the internal reliability of the coding. Two codings were compared with each other and reliability was calculated using Miles and Huberman's formula where reliability equals consensus divided by the sum of consensus plus disagreements then multiplied by 100 . The reliability study showed the agreement between the two codings to be $95 \%$.

\section{Data Analysis}

First, the recent list of educational journals indexed in the database of ULAKBIM and SSCI was found. The relevant articles were accessed on the journals' websites by examining them one by one. As a result, 98 articles were found for content analysis. Five articles were not subjected to analysis as they were published before 2005. The remaining 93 articles (13 experimental and 80 descriptive) were transferred to the Nvivo 10 program. 12 main themes and 84 subthemes, all different from each other, were created using the content analysis guidelines. Considering these themes, the 93 articles were read many times and relevant chapters were transferred to their own themes. As a result, the number of authors, number of participants, different journals in which articles were published according to year, and length of the experimental processes were determined, and average and standard deviations were calculated through the SPSS package program.

Data obtained at the end of the study was analyzed using the programs Microsoft Excel, SPSS-18, and Nvivo 10. Frequency and graphics are used to show the results of the analysis. The data obtained at the end of analysis are presented below based on the research questions.

\section{Findings}

\section{Subject of the Studies}

The distribution of studies on critical thinking skills is presented in Table 1. When Table 1 is analyzed, it can be seen that the studies on critical thinking skills were carried out on 13 different subjects. It can be seen that teacher candidates' critical thinking disposition ( $n=26$ ) was studied the most, and critical thinking and educational games and thinking styles and critical thinking subjects were studied the least.

\begin{tabular}{|c|c|c|}
\hline $\begin{array}{l}\text { Table } 1 \\
\text { Distribution of Studies on Critical Thinking Skills } \\
\text { Subject }\end{array}$ & & ding to \\
\hline The Distribution of Subjects & $f$ & $\%$ \\
\hline $\begin{array}{l}\text { The tendency of university students to use } \\
\text { critical thinking }\end{array}$ & 9 & 9.68 \\
\hline $\begin{array}{l}\text { The tendency of teacher candidates to use } \\
\text { critical thinking }\end{array}$ & 26 & 27.96 \\
\hline Critical thinking and educational games & 1 & 1.08 \\
\hline Evaluation of the program & 10 & 10.75 \\
\hline $\begin{array}{l}\text { The effect of critical thinking on the success of } \\
\text { secondary-school students }\end{array}$ & 8 & 8.60 \\
\hline $\begin{array}{l}\text { The effect of critical thinking on the success of } \\
\text { university students }\end{array}$ & 10 & 10.75 \\
\hline Thinking styles and critical thinking & 1 & 1.08 \\
\hline Teaching critical thinking & 5 & 5.38 \\
\hline Critical thinking and culture & 1 & 1.08 \\
\hline Learning styles and critical thinking & 3 & 3.23 \\
\hline Language skills and critical thinking & 8 & 8.60 \\
\hline $\begin{array}{l}\text { The effect of critical thinking on secondary- } \\
\text { school students }\end{array}$ & 6 & 6.45 \\
\hline The tendency of teachers to use critical thinking & 5 & 5.38 \\
\hline
\end{tabular}

\section{Year of Publication}

Distribution of studies on critical thinking skills according to the year of publication are presented in Chart 1 . According to Chart 1 , articles were mostly published in 2011 and 2013 with 15 articles in each of those years out of all 93 articles. In addition, 48 of the 93 studies related to critical thinking skills were published in the last four years (2011 - 2014).

\section{Gender of the Researchers ${ }^{1}$}

The distribution of researchers studying critical thinking skills according to gender is presented in Table 2. According to Table 2, 53 studies were carried out by female researchers and 40 were carried out by men.

Only the first authors of the studies were evaluated. 


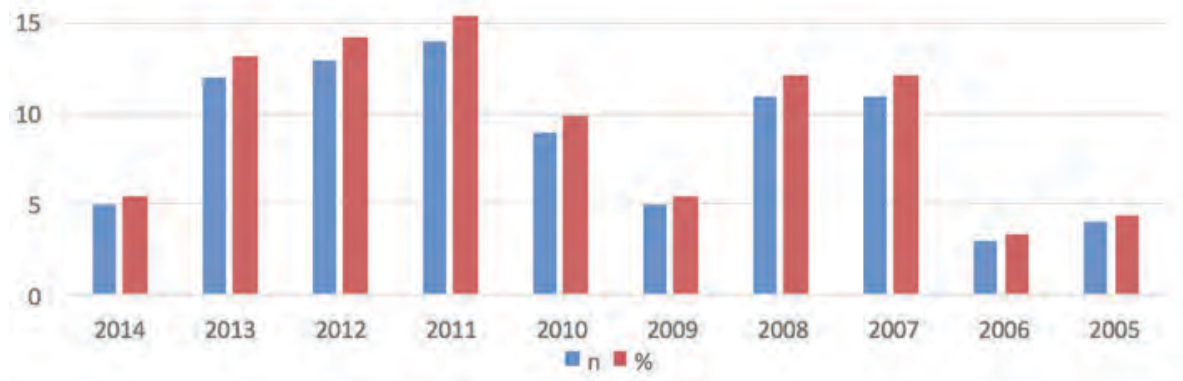

Chart 1: Distribution of studies on critical thinking skills according to the year of publication.

\begin{tabular}{lcc}
\hline $\begin{array}{l}\text { Table } 2 \\
\text { Distribution of Studies on Critical Thinking Skills According to } \\
\text { Gender of the Researcher }\end{array}$ & \\
\hline Gender & $f$ & $\%$ \\
\hline Male & 40 & 43.01 \\
Female & 53 & 56.99 \\
\hline
\end{tabular}

\section{Research Design}

Distribution of the studies on critical thinking skills according to research design is presented in Figure 1. When Figure 1 is examined, it is seen that nearly two-thirds, $(n=68)$ of the studies on critical thinking skills were conducted using the descriptive research design. Literature review and content analysis were the least frequently used ( $n$ $=6$ ) research designs. No study used the model development design.

\section{Method}

Distribution of studies on critical thinking skills according to research method is presented in Figure 2. When Figure 2 is examined, it can be seen that nearly two-thirds of the studies $(n=72)$ on critical thinking skills were carried out based on quantitative methods. The least preferred method was the mixed method $(n=4)$.

\section{Data Collection Instrument}

Distribution of studies on critical thinking skills according to the data collection instrument are presented in Figure 3. When Figure 3 is evaluated, it can be seen that the most preferred data collection instrument is scale $(n=62)$ and the least preferred one is observation form $(n=2)$ among the seven different data collection instruments.

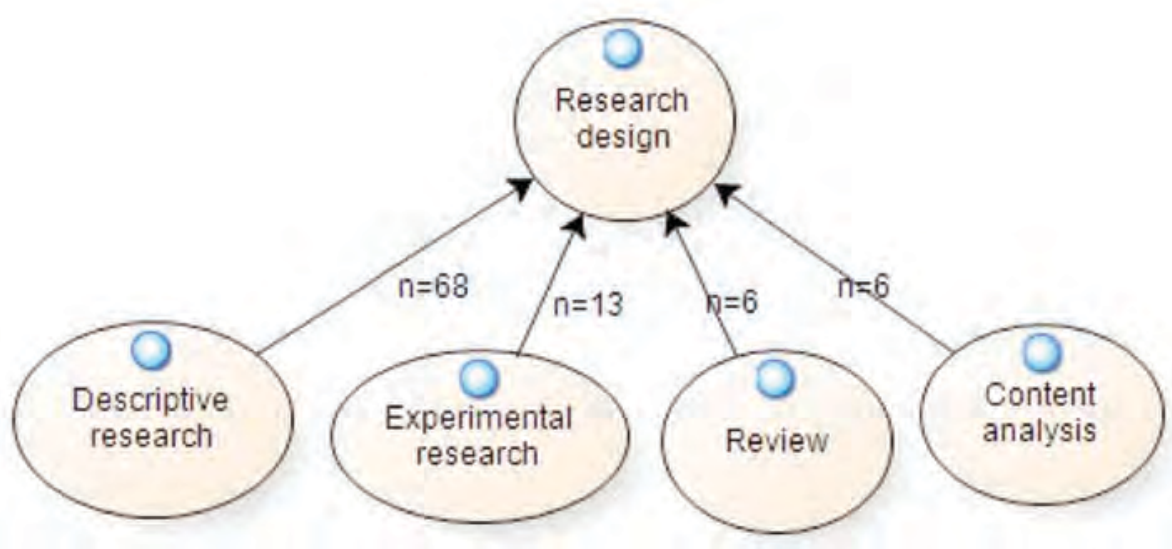

Figure 1: Distribution of the studies on critical thinking skills according to the research design. 


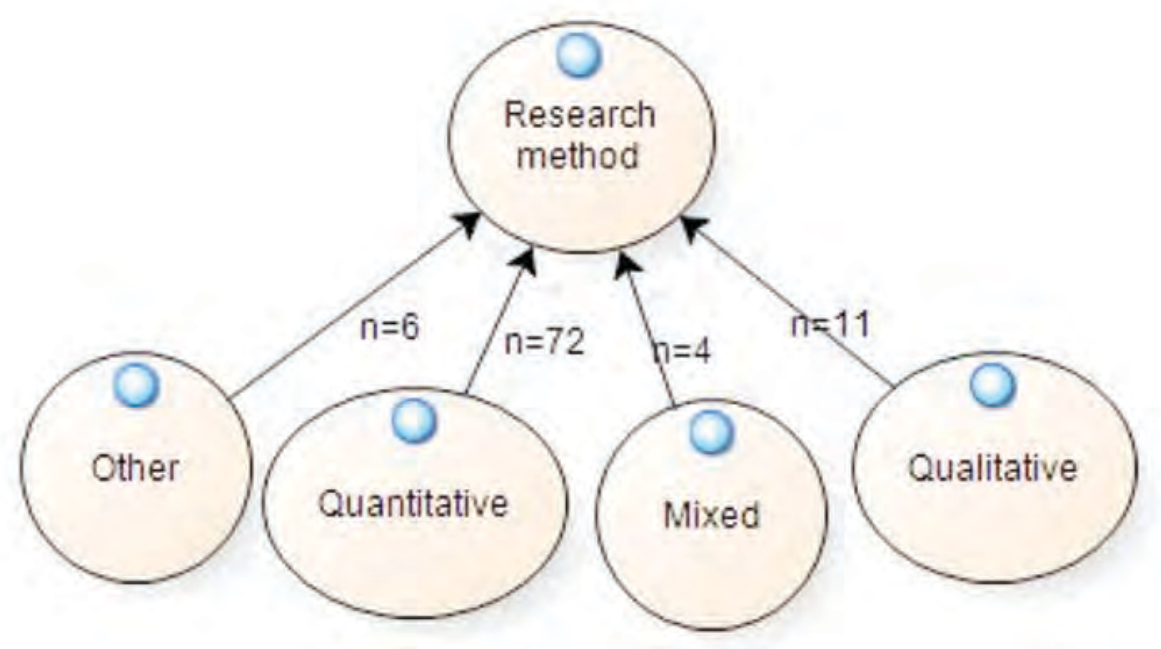

Figure 2: Distribution of studies on critical thinking skills according to research method.

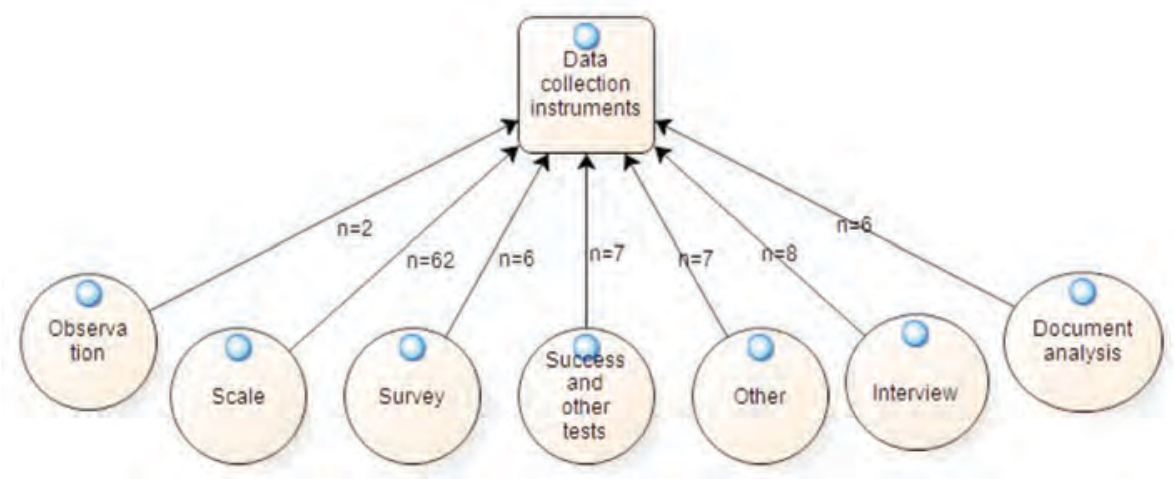

Figure 3: The distribution of subjects on critical thinking skills according to the data collection instrument.

\section{Sample Type}

Distribution of studies on critical thinking skills according to sampling type is presented in Figure 4. When Figure 4 is examined, it can be seen that more than half of the studies $(n=48)$ were conducted with teacher candidates. It is seen that the least $(n=1)$ studied group is primary-school students, and there have also been no studies at the kindergarten level.

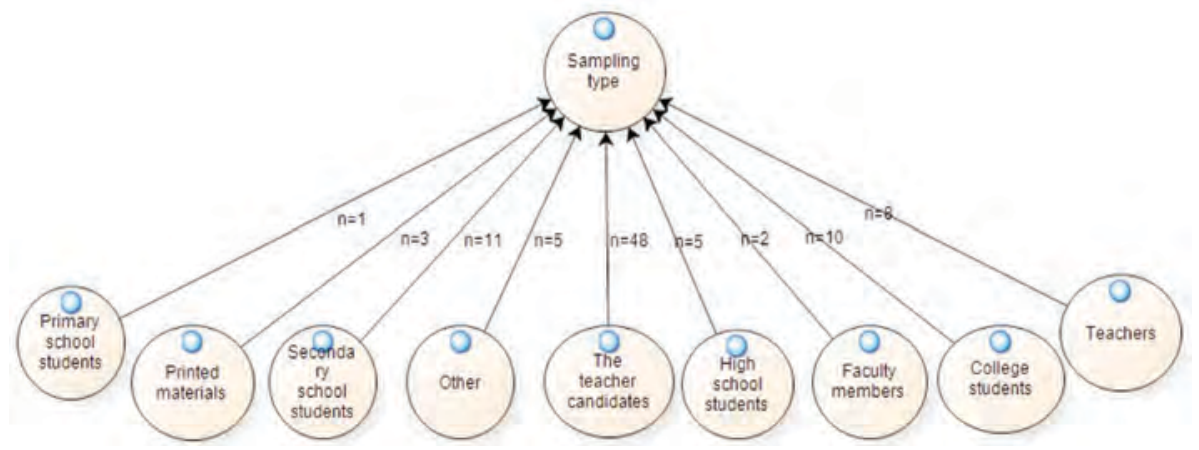

Figure 4: The distribution of subjects on critical thinking skills according to sampling type. 


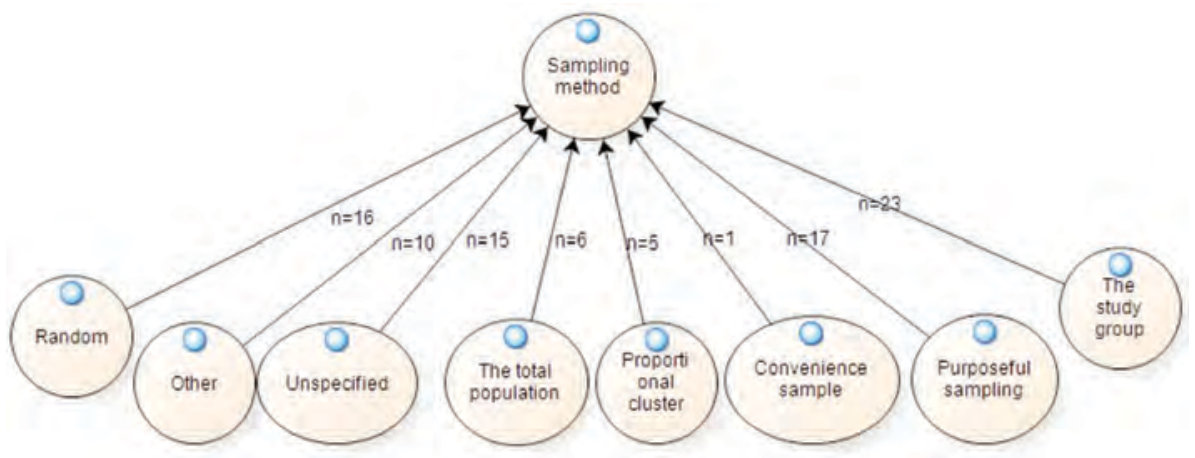

Figure 5: Distribution of studies on critical thinking skills according to sample method.

\section{Sampling Method}

The distribution of studies on critical thinking skills according to sampling type is presented in Figure 5. When Figure 5 is examined, we see that the most preferred group is the study group. Studies on critical thinking show that study group is the most preferred $(n=23)$. However, when the method of sampling from the universe is looked at, it is seen that purposeful sampling and random sampling are the most preferred $(n=17)$ and convenience sampling is the least preferred $(n=1)$.

\section{Extent of Sampling ${ }^{2}$}

The distribution of participants according to number is given in Table 3 . When Table 3 is examined, it can be seen that the total number of participants in studies on critical thinking skills range from 6 to 2488 , and the average number of participants per study is approximately 298 . The average number of participants for descriptive research is 338 and the average number of participants for experimental research is approximately 77 .

\begin{tabular}{lccccc}
\hline Table 3 \\
$\begin{array}{l}\text { Average Number of Participants in } \\
\text { Critical Thinking Skills Studies }\end{array}$ \\
\hline & $N$ & Minimum & Maximum & $X$ & SS \\
\hline Descriptive & 71 & 6 & 2488 & 338.77 & 428.06 \\
Experimental & 13 & 40 & 154 & 77.76 & 29.51 \\
\hline Total & 84 & 6 & 2488 & 298.38 & 404.58 \\
\hline
\end{tabular}

2 These numbers do not include the studies done in the patterns of content analysis and literature review.

\section{The Journals of the Studies ${ }^{3}$}

The distribution of articles on critical thinking according to the journals in which they were published is given in Table 4 . When Table 4 is analyzed, it can be seen that studies on critical thinking were published

Table 4

Distribution of Articles on Critical Thinking Ability According to Journals

\begin{tabular}{lll}
\hline Journal Title & $f$ & $\%$ \\
\hline Abant İzzet Baysal Üniversitesi Eğitim Fakültesi & 5 &
\end{tabular}

Dergisi

$\begin{array}{llll} & & 5.38 \\ \text { Ahi Evran Üniversitesi Eğitim Fakültesi Dergisi } & 9 & 9.68\end{array}$

Ankara Üniversitesi Eğitim Bilimleri Fakültesi

Dergisi

3.23

Atatürk Üniversitesi Sosyal Bilimler Enstitüsü

Dergisi

1.08

Çukurova Üniversitesi Eğitim Fakültesi Dergisi $\quad \begin{array}{lll}1 & 1.08\end{array}$

Çukurova Üniversitesi Sosyal Bilimler Enstitüsü 7

Dergisi

7.53

Dumlupınar Üniversitesi Eğitim Fakültesi Dergisi $\quad 2 \quad 2.15$

$\begin{array}{lll}\text { Eğitim Araştırmaları } & 7 & 7.53\end{array}$

Eğitim ve Bilim $\quad 4 \quad 4.30$

Elektronik Sosyal Bilimler Dergisi $\quad 2 \quad 2.15$

Gazi Eğitim Fakültesi Dergisi $\quad 4 \quad 4.30$

Hacettepe Üniversitesi Eğitim Fakültesi Dergisi $\quad 6 \quad 6.45$

İlköğretim Online $\quad 5 \quad 5.38$

İnönü Üniversitesi Eğitim Fakültesi Dergisi $\quad \begin{array}{lll}1 & 1.08\end{array}$

Kastamonu Üniversitesi Eğitim Fakültesi Dergisi $\quad 5 \quad 5.38$

$\begin{array}{lll}\text { Kuramsal Eğitimbilim } & 1 & 1.08\end{array}$

Kuram ve Uygulamada Eğitim Bilimleri Dergisi $\quad 8 \quad 8.60$

Kuram ve Uygulamada Eğitim Yönetimi Dergisi $\quad 2 \quad 2.15$

Mersin Üniversitesi Eğitim Fakültesi Dergisi $\quad 2 \quad 2.15$

$\begin{array}{lll}\text { Millî Eğitim Dergisi } & 1 & 1.08\end{array}$

Mustafa Kemal Üniversitesi Sosyal Bilimler 33.23

Enstitüsü Dergisi

Ondokuz Mayıs Üniversitesi Eğitim Fakültesi 111.08

Dergis

Pamukkale Üniversitesi Eğitim Fakültesi Dergisi $\quad 1 \quad 1.08$

$\begin{array}{lll}\text { Sosyal Bilimler Araștırmaları Dergisi } & 1 & 1.08\end{array}$

$\begin{array}{lrr}\text { TOJET } & 2 & 2.15\end{array}$

$\begin{array}{lll}\text { Turkish Studies } & 6 & 6.45\end{array}$

Türk Psikolojik Danışma ve Rehberlik Dergisi $\quad \begin{array}{lll}1 & 1.08\end{array}$

Uludağ Üniversitesi Fen-Edebiyat Fakültesi 111.08

Sosyal Bilimler Dergisi

Uluslararası Türkçe Edebiyat Kültür Eğitim Dergisi $\quad \begin{array}{lll}1 & 1.08\end{array}$

3 As the journals about critical thinking skill, the articles were not analyzed by Nvivo. 
in 29 different journals. It can also be seen that writers prefer "Ahi Evran University Faculty of Education Journal" $(n=9)$, "Educational Sciences: Theory \& Practice" $(n=8)$, "Çukurova University Social Sciences Institute Journal" ( $n=7)$ and "Educational Research" $(n=7)$ journals over the others.

\section{Number of Authors in the Articles}

The distribution of articles according to the number of authors is given in Table 5. When Table 5 is examined, it can be seen that the number of authors in the studies ranged between 1 and 3 , and the mean number of authors appears to be approximately 2 .

Table 5

Number of Authors in Articles on Critical Thinking Skills

\begin{tabular}{lcccccc}
\hline & $N$ & Minimum & Maximum & $X$ & SS \\
\hline $\begin{array}{l}\text { Number } \\
\text { Authors }\end{array}$ & of & 93 & 1 & 3 & 1.66 & .634 \\
\hline
\end{tabular}

\section{The Courses in which Experimental Studies are Performed}

The distribution of courses in which experimental studies were carried out is presented in Table 6 . Table 6 shows that science and technology courses ( $n=2$ ) were the most preferred in studies on critical thinking skills. However, it can be seen that only one study was carried out in each of the other lessons. There have not been any studies regarding Math or English classes.
Table 6

Courses in Which Experimental Studies on Critical Thinking Skills were Studied

\begin{tabular}{lcc}
\hline The Lessons in Which Experimental Studies are & $f$ & $\%$ \\
Conducted & 1 & 7.69 \\
\hline Turkish Education & 1 & 7.69 \\
Turkish & 3 & 23.07 \\
Science and Technology & 1 & 7.69 \\
Social Studies & 1 & 7.69 \\
The Techniques of Psychological Consultation & 1 & 7.69 \\
History of Science & 1 & 7.69 \\
Geography & 1 & 7.69 \\
General Biology & 1 & 7.69 \\
Introduction to Computers & 1 & 7.69 \\
Thinking skills & 1 & 7.69 \\
Teaching Social Studies &
\end{tabular}

\section{The Implementation Period of Experimental Studies}

The distribution of experimental studies according to the application period is given in Table 7 . When Table 7 is examined, it can be seen that the experimental period ranged from 3 to 15 weeks and the average duration was approximately 8 weeks.

\begin{tabular}{llllll}
\hline $\begin{array}{l}\text { Table } 7 \\
\text { Implementation } \\
\text { Thinking Skills }\end{array}$ & Period in Experimental Studies & on & Critical \\
& $N$ & Minimum & Maximum & $X$ & SS \\
\hline $\begin{array}{l}\text { Implementation } \\
\text { Period }\end{array}$ & 13 & 3 & 15 & 8.23 & 4.24 \\
\hline
\end{tabular}

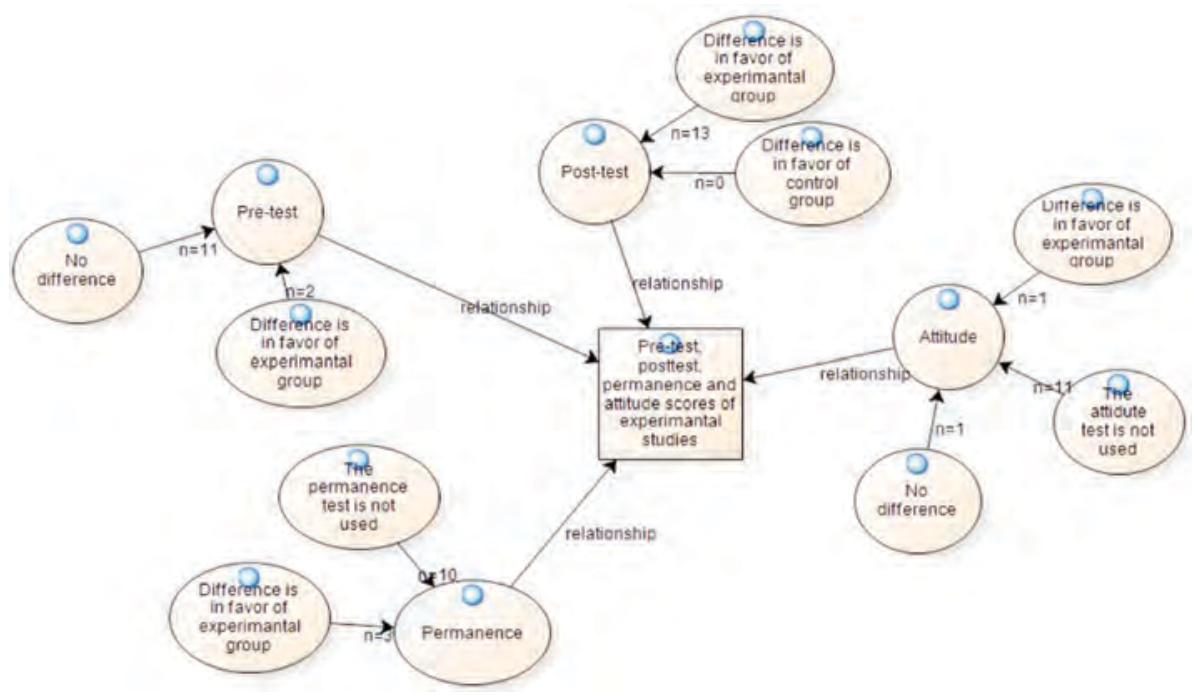

Figure 6: The comparison of the score differences for pretest, post-test, persistence, and attitude. 
Pretest, Post-test, Retention, and Attitude Scores of Experimental and Control Groups in Experimental Studies

The distribution of score differences among pretest, post-test, retention, and attitude scores of experimental and control groups is presented in Figure 6 . When Figure 6 is examined, it can be seen that there was not any difference $(n=11)$ in the pretest scores for experimental studies. In the posttests, the difference was in favor of the experimental groups in all studies. The retention test was used in only three studies. The difference emerged in favor of experimental groups in these studies. In two of the experimental studies, the attitude test was used. In one study, the difference was found in favor of the experimental group. In the other study, there was no difference between the mean scores.

\section{Education Level of the Students in Experimental Studies}

The distribution of students in experimental studies according to their level of education is presented in Table 8. Analyzing Table 8, it can be seen that the vast majority of $(n=9)$ experimental studies on critical thinking skills were carried out in higher education schools. However, only four studies were carried out in secondary schools. No studies were conducted in kindergarten, elementary schools, or high schools.

\begin{tabular}{lcc}
\hline Table 8 \\
Education Levels of Students who participated in Experimental \\
Studies on Critical Thinking Skills \\
\hline $\begin{array}{l}\text { Education Level of Students who Participated in } \\
\text { Experimental Studies }\end{array}$ & f & $\%$ \\
\hline Secondary School & 4 & 30.77 \\
University & 9 & 69.23 \\
\hline
\end{tabular}

\section{Word Frequency in Articles ${ }^{4}$}

The distribution of words used in studies on critical thinking skills according to frequency is presented in Figure 7. When Figure 7 is analyzed, it is identified that the most commonly used word is critical ( $n=7298)$ and the least used one is mistake $(n=81)$.

4 Reviewing in the articles are limited with at least four letters.

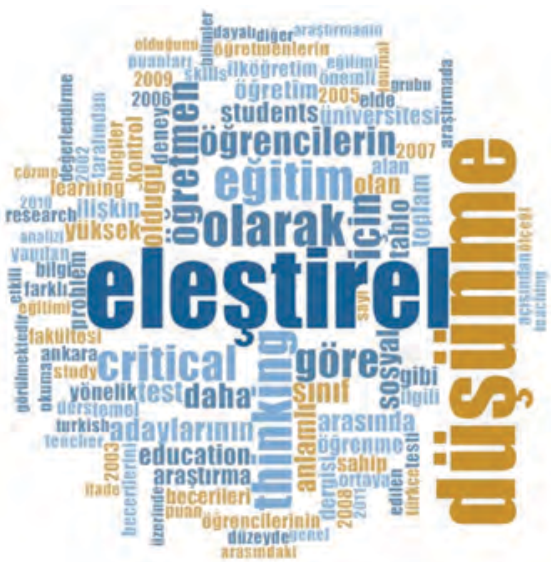

Figure 7: Word frequency of studies on critical thinking.

\section{Conclusion, Discussion, and Recommendations}

In this study, 93 articles on critical thinking skills from 29 journals, which are indexed in SSCI and the ULAKBİM database in Turkey as well as written in both English and Turkish were examined. The evaluation was done according to the findings obtained from thematic content analysis.

Between 2005 and 2014, studies on critical thinking skills were conducted with 13 different subjects. Although the studies were carried out with different subjects, the majority of these studies seems to be abouteacher candidates attitudes on critical thinking. Content analysis from Saban (2008) about the Multiple Intelligence Theory shows that most studies are based on one topic and the program practitioners are teachers. Thus, it can be said that the number of studies about teachers and programs needs to be increased. However, it stands to note that there has not been an efficient study about critical reading and writing for primary school, secondary school, high school or university students.

Publications on critical thinking skills have shown an increase over the last four years $(2011,2012$, 2013 and 2014). This situation shows that the interest of Turkish education researchers on critical thinking skills is increasing. When studies are evaluated in terms of gender of the researchers, it is seen that women researchers are more interested in studies on critical thinking skills. Also, for the number of authors, it is obvious that there are more studies with just one author than multiple authors. In particular, the articles in SSCI journals were written mostly by one author. This situation is a result of the necessity of being the sole author of a research for obtaining associate professorship in 
the Turkish science education system. The majority of articles examined by Varışoğlu et al. (2013) were written by one author.

In analyzing the distribution of studies according to research design, it is seen that nearly two-thirds of the studies are conducted using descriptive research design. Thus, it can be said that the possibility of descriptive studies is high while studying a novel concept. In a study conducted by Aktaş (2013), it was identified that the descriptive research design is preferred, especially by Turkish authors. There seems to be very few studies regarding literature review and content analysis. It can be said that studies regarding content analysis need to increase because the ability of critical thinking has been accepted as a main skill especially in Turkish education programs. However, none of the studies aimed to develop a model regarding critical thinking skills. Analysis of the distribution of studies on critical thinking according to research methods shows that nearly two-thirds of the studies are conducted on the basis of the quantitative method. This evidence is supported by the findings of the study by Çiltaş, Güler, and Sözbilir (2012). There is a need for studies which are carried out using mixed methods, which is the least preferred method. In the study by Göktaş et al. (2012) it is seen that studies using mixed methods are much less preferred at rate of $3.4 \%$. There have not been any studies using action research. There is a need for action research studies in which critical writing will be used.

Examining the distribution of studies on critical thinking skills according to data collection instrument, it is seen that scales are the most preferred and observation is the least preferred instrument in the studies which overall used 7 different data collection instruments. It is seen that the most preferred scale is the California Critical Thinking Disposition Inventory (CCTDI) scale. Indeed, this scale adopted by Kökdemir (2003) to Turkish is also used. In this study, the 75-item scale was reduced to 51 items. However, analyzing the studies in literature, the scale was also adopted to Turkish by İskifoğlu and Ağazade (2013) and its factor, reliability, and validity analyses were analyzed. Turkish adaptation of the scale preserved the number of items and their original dimensions. But when articles in Turkey are looked at, it is noticeable that the adapted version of this scale has not yet been used.

Analyzing the distribution of studies on critical thinking skills according to their sampling type between the years 2005 and 2014, it is seen that more than half of the studies were carried out with candidate teachers. There have only been only four studies at the secondary-school level, one study in primary school and no studies at the kindergarten level. Therefore, there is a need for studies regarding students in primary schools and kindergarten. In the study of Baki, Güven, Karataş, Akkan, and Çakıroğlu (2011), "Mathematics Education Research in Turkey," it is seen that mostly secondary-school students are preferred as a sample type. When studies analyzed in terms of sample features, it is seen that researchers mostly prefer study groups. However, when looking at the method of sampling from the universe, it is seen that the most preferred methods are purposeful sampling and random sampling. In 15 studies, even though researchers mentioned the concepts of universe and sample, they did not mention how they get their samples from the universe. In the study by Ulutaş and Ubuz (2008), it is stated that most studies don't mention sample features.

Between the years 2005 and 2014, there have been a total of 72 studies on critical thinking skills based on quantitative methods. Among them, there have been 13 experimental studies. Therefore, it can be said that experimental studies are small in number. In the studies of Saban (2008) and Çiltaş et al. (2012), the number of experimental studies were outstanding. This case reduces the number of courses in which experimental studies were carried out. Although critical thinking skills have a place in primary school curriculum as an essential skill, more than half of the experimental studies are at the level of undergraduate education and there have not been any studies for kindergarten, elementary, or secondary education levels. This case shows that experimental studies regarding primary and secondary education are needed. There is also a need for studies especially regarding Math and English courses because there is an absence of studies on them. Judge, Jones, and McCreery (2009) present that critical thinking studies can be applied to any level of education. Nosich (2012) also explains through examples that critical thinking can be applied to all lessons.

Examining the distribution of scores among pretest, post-test, retention, and attitude scores of experimental and control groups, there weren't any differences in the mean scores of the pretests in experimental studies. In the post-tests, the difference was in favor of experimental groups. So it can be said that instruction based on critical thinking is effective. The retention test was used in only three experimental studies on critical thinking 
skills. In 11 experimental studies, the attitude test was not used. To identify student reactions to the courses, the attitude test in experimental studies is highly important.

Analyzing the frequency of words used in the studies, it is seen that the most commonly used word is critical and the least used word is mistake.

With the results obtained from studies in Turkey on the field of critical thinking skills, the recent tendency of articles has been attempted to be put forth. The result of this study is believed to be a guide for new research. In this respect, the recommendations of the researcher for future studies in similar or related studies are as follows. (i) Papers presented in congress, symposiums, or theses written in Turkey lie beyond the scope of this study. Therefore, new research based on symposium and congress papers as well as theses can bring new perspectives to the implementation of critical thinking skills in the Turkish education system. (ii) It has been discovered in this study that the number of researches using experimental methods, mixed methods, or action researches are very limited. Therefore, studies based on experimental methods, mixed methods, and action researches can be carried out. (iii) It has been discovered that two-thirds of the studies use scales as data collection instruments. Therefore, studies can focus on different data collection instruments other than scales. (iv) It has been found that the sample of the studies are generally teacher candidates. Research can be done with different samples other than teacher candidates. (v) In experimental studies, researchers can focus on elementary and secondary schools. (vi) According to the results of this study, there have been no studies about Math or English lessons, therefore studies can be carried out on these subjects as well.

\section{References}

Aktaş, M. C. (2013). Yeni matematik öğretim programları ile ilgili araştırmalar için 5n- 1k: Lisansüstü tezler. Millî Eğitim Dergisi, 197(42), 209-226.

Baki, A., Güven, B., Karataş, İ., Akkan, Y., \& Çakıroğlu, Ü. (2011). Türkiye'deki matematik eğitimi araştırmalarındaki eğilimler: 1998 ile 2007 yılları arası, Hacettepe Üniversitesi Eğitim Fakültesi Dergisi, 40, 57-68.

Balc1, A. (2011). Sosyal bilimlerde araştırma yöntem, teknik ve ilkeler (9th ed.). Ankara: Pegem Akademi.

Bayat, N. (2014). Öğretmen adaylarının eleştirel düşünme düzeyleri ile akademik yazma başarıları arasındaki ilişki. Ĕ̌itim ve Bilim, 39(173), 155-168.

Beyer, B. (1987). Practical strategies for the teaching of thinking. Boston, MA: Allyn and Bacon.

Cüceloğlu, D. (1995). İyi düşün doğru karar ver (10th ed.). İstanbul: Sistem Yayıncilık.

Çalık, M., \& Sözbilir, M. (2014). İçerik analizinin parametreleri. Eğitim ve Bilim, 39(174), 33-38.

Çiltaş, A., Güler, G., \& Sözbilir, M. (2012). Türkiye’de matematik eğitimi araştırmaları: Bir içerik analizi çalışması. Kuram ve Uygulamada Eğitim Bilimleri, 12, 565-580.

Dewey, J. (1910). How we think, mass. Boston, MA: D. C. Health \& Co.

Ennis, R., H (1985). A logical basis for measuring critical thinking skills. Retrieved from http://www.ascd.org/ASCD/ pdf/journals/edİlead/elİ198510İennis.pdf

Glesne, C. (2013). Nitel araştırmaya giriş (trans. A. Ersoy \& P. Yalçınoğlu). Ankara: Anı yayıncılık.

Göktaş, Y., Hasançebi, F., Varışoğlu, B., Akçay, A., Bayrak, N., Baran, M., \& Sözbilir, M. (2012). Türkiye'deki eğitim araștırmalarında eğilimler: Bir içerik analizi. Kuram ve Uygulamada Eğitim Bilimleri, 12, 443-460.

Gülbahar, Y., \& Alper, A. (2009). Öğretim teknolojileri alanında yapılan araștırmalar konusunda bir içerik analizi. Ankara Üniversitesi Eğitim Bilimleri Fakültesi Dergisi, 42(2), 93-111.

Hançerlioğlu, O. (2007). Düşünce tarihi. İstanbul: Remzi Kitabevi.

İskifoğlu, G., \& Ağazade, A. S. (2013). Translation and validation of a Turkish version of the California Critical Thinking Disposition Inventory. Social Behavior and Personality, 41(2), 187-196.

İskifoğlu, G. (2014). Cross-cultural equivalency of the California Critical Thinking Disposition Inventory. Educational Sciences: Theory \& Practice, 14, 159-178.

Judge, B., Jones, P., \& Mccreery, E. (2009). Study skills in education. London: Learning Matters.

Karadağ, E. (2009). Eğitim bilimleri alanında yapılmış doktora tezlerinin incelenmesi. Ahi Evran Üniversitesi Ĕ̆itim Fakültesi Dergisi, 10(3), 75-87.

Kazanc1, O. (1989). Eğitimde eleştirici düşünme ve öğretimi. İstanbul: Kazancı Kitap A.Ş.

Kocahanoğlu, O. S. (2003). Mustafa Kemal Atatürk Nutuk (söylev). İstanbul: Temel Yayınları. 
Kökdemir, D. (2003). Belirsizlik durumlarında karar verme ve problem çözme (Doctoral dissertation, Ankara University, Ankara). Retrieved from http://tez2.yok.gov.tr/

Merriam, S. B. (2013). Nitel araștırma desen ve uygulama için bir rehber (trans. S. Turan). Ankara: Nobel Yayınevi.

Miles, H. B., \& Huberman, A. M. (1994). Qualitative data analysis. Thousand Oaks, CA: Sage.

Nahifi, S., \& Çelebioğlu, A. (2008). Mevlana mesnevi-i șerif. İstanbul: Timaş Yayınları.

Nosich, G. M. (2012). Eleștirel düşünme rehberi (trans. B. Aybek). Ankara: Anı Yayıncılık.

Özçınar, N. H. (1996). Orta seviyede İngilizce üniversite ögrencilerinin eleștirel düşünce yeteneklerinin artırılması (Master's thesis, Middle East Technical University, Ankara, Turkey). Retrieved from http://tez2.yok.gov.tr/

Özden, Y. (2000). Öğrenme ve öğretme. Ankara: Pegema Yayıcilık.
Patton, M. Q. (2014). Nitel araştırma ve değerlendirme yöntemleri (trans. M. Bütün \& M. S. Demir). Ankara: Pegem Akademi.

Saban, A. (2008). Çoklu zekâ kuramı ile ilgili Türkçe çalışmaların içerik analizi. Kuram ve Uygulamada Eğitim Bilimleri, 9(2), 833-876.

Sözbilir, M., \& Kutu, H. (2008). Development and current status of science education research in Turkey [Special Issue]. Essays in Education, 1-22. Retrieved from http:// www.usca.edu/essays/

Ulutaş, F., \& Ubuz, B. (2008). Matematik eğitiminde araștırmalar ve eğilimler: 2000 ile 2006 yılları arası. İlkögretim Online, 7(3), 614-626.

Varışoğlu, B., Şahin, A., \& Göktaş, Y. (2013). Türkçe eğitimi araştırmalarında eğilimler. Kuram ve Uygulamada Eğitim Bilimleri, 13, 1767-1781.

Yangın, S. (2014). Porphyries ağacına dayalı uygulamaların sınıf öğretmeni adaylarının düşünme becerilerine etkisi. Turkish Studies - International Periodical for The Languages, Literature and history of Turkish or Turkic, 9(2), 1597-1620. 